\title{
EFEK INFUSA AKAR TEMPUYUNG (SONCHUS ARVENSIS) TERHADAP PENURUNAN KADAR ASAM URAT PADA TIKUS PUTIH (RATTUS NORVEGICUS)
}

\author{
Kurnia Retnowati ${ }^{1}$, EM Sutrisna ${ }^{2}$, Iin Novita NM$^{2}$ \\ ${ }^{1}$ Faculty of pharmacy Muhammadiyah University of Surakarta \\ ${ }^{2}$ Department of Farmakology of Faculty of Medicine \& faculty of pharmacy of Universitas Muhammadiyah Surakarta
}

\begin{abstract}
Tempuyung (Sonchus arvensis) consisted of flavonoid were effect as obstruct xantine oksidase enzyme, antioxidant captur superoxsidase radical. The flavonoid total in leave of tempuyung is $0,1044 \%$, in its root have $0,5 \%$ flavonoid and the more is apigenin-7-O-glikosida $(3,4,5)$. This research aim to know effect of infusa root of tempuyung (Sonchus arvensis) to lower the uric acid level at blood serum and infusa root of Tempuyung (Sonchus arvensis) to lower the uric acid level at mouse blood serum compared to allopurinol.This research is laboratory experimental method. The object were 25 Wistar male mice 2-3 months old, 150-200 gr divided into 5 groups. Negative Control group given potassium oxonate by intraperitoneal, Positive Control group given potassium oxonate by intraperitoneal, added by allopurinol $18 \mathrm{mg} / \mathrm{kgBB}$, Infusa Concentrated Group 1 given potassium oxonate by intraperitoneal added by infusa root of tempuyung $1,25 \mathrm{~g} / \mathrm{kgBB}$, Infusa Concentrated Group 2 given potassium oxonate by intraperitoneal added by infusa root of tempuyung 2,5g/kgBB, Infusa Concentrated Group 3 given potassium oxonate by intraperitoneal added by infuse root of tempuyung $5 \mathrm{~g} / \mathrm{kgBB}$. Executed until one day, where measurement of uric acid of mouse blood serum done before and after treatment. Measurement of uric acid level is done by using spectrophotometer. Obtained to be data to be analysed with Kolgomorov-Smirnov test, One-Way ANOVA and continued with LSD (Least Significant Difference) test with 95\% confidence interval (CI). Result of statistical test of research shoe that infusa root of Tempuyung (Sonchus arvensis) dose 1,25g/kgBB, 2,5g/ $\mathrm{kgBB}, 5 \mathrm{~g} / \mathrm{kgBB}$ have effect to lower the uric acid level at mouse blood serum. Infusa root of Tempuyung (Sonchus arvensis) concentrated $5 \mathrm{~g} / \mathrm{kgBB}$ proportional wih dose allopurinol $18 \mathrm{mg} / \mathrm{kgBB}$ to lower the uric acid level at mouse blood serum.
\end{abstract}

Keyword: Infusa, root of Tempuyung (Sonchus arvensis), uric acid

\section{PENDAHULUAN}

Penyakit gout pada umumnya terjadi karena tingginya kadar purin dalam tubuh. Kadar purin yang tinggi lama-kelamaan akan menimbulkan rasa tidak nyaman di sendi dan bahkan menimbulkan rasa sakit yang sangat hebat pada persendiaan kaki, punggung, serta persendian tangan dan jari (Mahendra, 2006).

Asam urat adalah hasil produksi oleh tubuh sehingga keberadaanya normal dalam darah dan urin. Namun bila produksi asam urat menjadi sangat berlebihan atau pembuangannya berkurang, akibatnya kadar asam urat dalam darah tinggi (Misnadiarly, 2007). Kadar asam urat yang tinggi dapat mengendap pada persendian sentral dan jaringan mesenkim seperti ginjal. Keadaan ini semakin lama semakin berat. Maka asam urat yang berlebihan di dalam tubuh harus dikeluarkan atau dihambat produksinya (Yatim, 2006).

Tanaman obat asli Indonesia (OAI), berdasarkan kandungan kimianya, mempunyai indikasi untuk mengatasi asam urat tersebut. Senyawa kimia yang diperkirakan mempunyai efek mencegah pembentukan asam urat adalah flavonoid. Dari sekian banyak tumbuhan yang mengandung senyawa flavonoida tadi, yang cukup dikenal adalah tempuyung (Sonchus arvensis) (Widisih, 2004). Akar tempuyung mengandung senyawa flavonoid total kira-kira $0,5 \%$ dan flavonoid yang terbesar adalah apigenin7-0-glukosida (Sulaksana, 2004). Pada penelitian oleh Farid, ekstrak daun tempuyung (Sonchus arvensis) dapat menurunkan kadar asam urat pada serum darah tikus putih (Rattus Norvegicus) 
(Farid, 2007). Penelitian ini bertujuan untuk mengetahui pengaruh infusa akar tempuyung terhadap penurunan kadar asam urat pada tikus putih.

\section{METODE PENELITIAN}

Penelitian ini menggunakan desain penelitian eksperimental kuasi, dengan menggunakan metode pre and post test control group design dengan alokasi random untuk mengetahui pengaruh infusa akar tempuyung terhadap penurunan kadar asam urat pada tikus putih (Pratiknya, 2000). Penelitian dilaksanakan di laboratorium farmakologi Fakultas Kedokteran UMS. Hewan uji yang digunakan adalah Tikus putih jantan galur Wistar yang Sehat dan mempunyai aktivitas normal, Berumur 2-3 bulan dan Berat badan 150-200 gram. Tikus menderita sakit/mati saat penelitian berlangsung dieksklusi. Bahan untuk pengukuran asam urat adalah reagen Uric Acid FS*TBHBA(2,4,6-Tribromo-3hydroxybenzoid acid) (DyaSys). Komposisi dari reagen uric acid FS* TBHBA.

\section{Cara Kerja}

a. Mula-mula tikus putih (Rattus norvegicus) diadaptasi selama kurang lebih 3 hari dengan lingkungan yang baru dan dipuasakan kurang lebih 18 jam sebelum penelitian dengan tetap diberi makanan standar untuk tikus (pellet) dan minuman (aqua ad libida)

b. Tikus ditimbang berat badannya kemudian dibagi menjadi 5 kelompok masing-masing 5 ekor tikus, diukur kadar asam urat awal.

c. Kelompok I sebagai kontrol negatif terdiri dari 5 ekor tikus putih yang diberi aqua proinjeksi secara peroral diamkan selama 1,5 jam. Setelah 1,5 jam ditambah potassium oxonat $250 \mathrm{mg} /$ $\mathrm{kgBB}$ secara intraperitoneal setelah 1,5 jam darah diambil.

d. Kelompok II sebagai kontrol positif terdiri dari 5 ekor tikus putih diberi allopurinol dosis $5,4 \mathrm{mg} /$ hari secara peroral diamkan selama 1,5 jam. Setelah 1,5 jam ditambah potassium oxonat $250 \mathrm{mg} / \mathrm{kgBB}$ secara intraperitoneal setelah 1,5 jam darah diambil.

e. Kelompok III sebagai kelompok dosis satu yang terdiri 5 ekor tikus putih diberi infusa akar tempuyung konsentrasi pertama $(10 \%)$ secara peroral diamkan selama 1,5 jam. Setelah 1,5 jam ditambah potassium oxonat $250 \mathrm{mg} / \mathrm{kgBB}$ secara intraperitoneal setelah 1,5 jam darah diambil.

f. Kelompok IV sebagai kelompok dosis kedua yang terdiri 5 ekor tikus putih diberi infusa akar tempuyung konsentrasi kedua (20\%) secara peroral diamkan selama 1,5 jam. Setelah 1,5 jam ditambah potassium oxonat $250 \mathrm{mg} / \mathrm{kgBB}$ secara intraperitoneal setelah 1,5 jam darah diambil.

g. Kelompok V sebagai kelompok dosis ketiga yang terdiri 5 ekor tikus putih diberi infusa akar tempuyung konsentrasi ketiga (40\%) secara peroral diamkan selama 1,5 jam. Setelah 1,5 jam ditambah potassium oxonat $250 \mathrm{mg} / \mathrm{kgBB}$ secara intraperitoneal setelah 1,5 jam darah diambil.

h. Kelima kelompok diambil darahnya untuk diperiksa kadar asam urat plasma pada hari sebelum perlakuan dan setelah perlakuan. Cara pengambilan darah:

1. Pipa kapiler yang telah dilapisi heparin ditusukkan pada ekor tikus putih.

2. Darah yang keluar lewat pipa kapiler ditampung dalam tabung centrifuge yang di pegang miring. Darah dialirkan lewat dinding tabung centrifuge untuk menghindari terjadinya hemolisis.

3. Setelah itu darah $( \pm 1 \mathrm{ml})$ dicentrifuge selama 15-20 menit (1500 rpm) dan diambil serumnya.

4. $10 \mu \mathrm{l}$ serum $+500 \mu 1$ reagen asam urat (Biomerieux) diinkubasi selama 10 menit pada suhu $20^{\circ} \mathrm{C}-25^{\circ} \mathrm{C}$, kemudian dibaca pada photometer.

5. Hasil pengukuran kelima kelompok dibandingkan dengan uji ANOVA dan post hoc.

\section{HASIL DAN PEMBAHASAN}

Data hasil pengukuran untuk masingmasing kelompok, yaitu kelompok kontrol negatif, kelompok kontrol positif, kelompok perlakuan konsentrasi infusa 10\%, kelompok perlakuan konsentrasi 20\%, kelompok perlakuan konsentrasi $40 \%$, disajikan pada tabel 1. 
Tabel 1. Rata-rata Persentase Perbandingan Hasil Pengukuran Kadar Asam Urat Serum Darah Tikus Setelah Perlakuan

\begin{tabular}{lc}
\hline \multicolumn{1}{c}{ Kelompok Perlakuan } & Rata-rata Perbandingan Kadar Asam Urat \\
& Setelah Perlakuan \\
\hline Kontrol Negatif & $161,2820 \pm 19,68688$ \\
Kontrol Positif & $42,2380 \pm 8,81502$ \\
Infusa Akar Tempuyung 10\% & $67,2920 \pm 6,58555$ \\
Infusa Akar Tempuyung 20\% & $57,0520 \pm 8,62479$ \\
Infusa Akar Tempuyung 40\% & $37,9940 \pm 2,94120$ \\
\hline
\end{tabular}

Tabel 1 memperlihatkan bahwa tampak efek penurunan kadar asam urat dimana hasil ratarata kelompok kontrol positif yang diberi preparat allopurinol 5,4mg/hari dan kelompok infusa akar tempuyung konsentrasi $40 \%$ tidak jauh berbeda. Hasil tersebut juga dapat terlihat pada diagram perbandingan nilai rata-rata asam urat masingmasing kelompok.

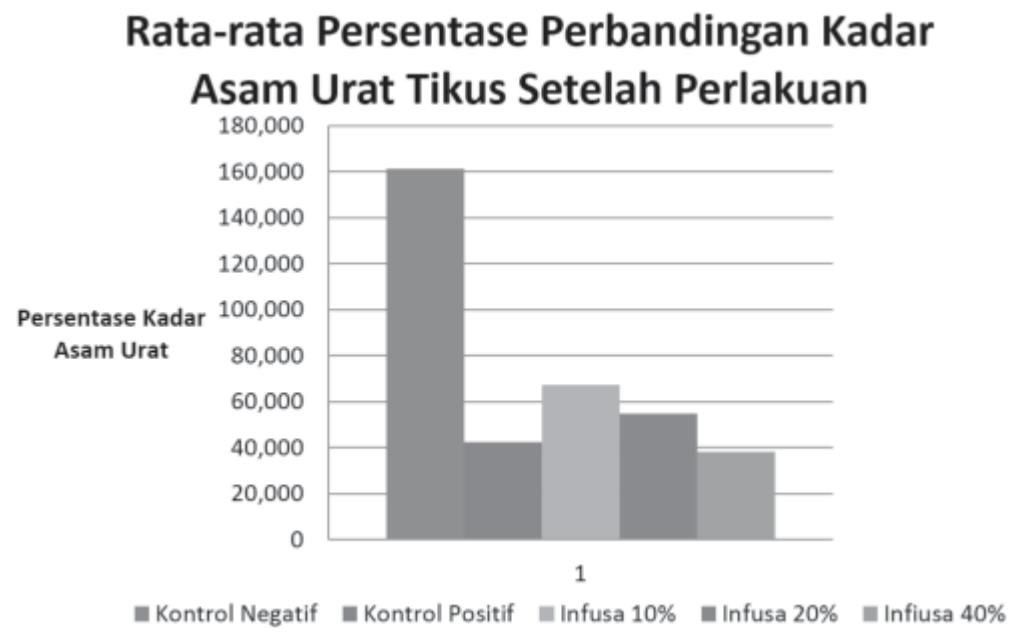

Gambar 1.Diagram Persentase Perubahan Kadar Asam Urat Setelah Perlakuan

Hasil perhitungan statistik dengan Oneway Anova menunjukkan nilai P. $0.001(<0,05)$. Hasil uji tersebut didapatkan perbedaan yang bermakna antara kelompok perlakuan. Kemudian diuji dengan uji LSD, hasil uji LSD menunjukkan perbandingan data yang dapat dilihat pada tabel 2 .

Tabel 2. Hasil Analisis Uji Statistik LSD Setelah Perlakuan

\begin{tabular}{ccc}
\hline Kelompok Perlakuan & Nilai p & Hasil uji \\
\hline I-II & 0,000 & Berbeda bermakna \\
I-III & 0,000 & Berbeda bermakna \\
I-IV & 0,000 & Berbeda bermakna \\
I-V & 0,000 & Berbeda bermakna \\
II-III & 0,002 & Berbeda bermakna \\
II-IV & 0,044 & Berbeda bermakna \\
II-V & 0,542 & Berbeda tidak bermakna \\
III-IV & 0,083 & Berbeda tidak bermakna \\
III-V & 0,000 & Berbeda bermakna \\
IV-V & 0,023 & Berbeda bermakna \\
\hline
\end{tabular}

\begin{tabular}{|c|c|}
\hline \\
\hline & \\
\hline \multirow{2}{*}{\multicolumn{2}{|c|}{$\begin{array}{ll}\text { I } & : \text { Kelompok kontrol negatif } \\
\text { II } & : \text { Kelompok kontrol positif }\end{array}$}} \\
\hline & \\
\hline \\
\hline \multicolumn{2}{|r|}{$\begin{array}{l}\text { : Kelompok perlakuan infusa akar tempuyung konsentrasi } 1(10 \%) \\
\text { : Kelompok perlakuan infusa akar tempuyung konsentrasi } 2(20 \%)\end{array}$} \\
\hline \multicolumn{2}{|r|}{ : Kelompok perlakuan infusa akar tempuyung konsentrasi $3(40 \%)$} \\
\hline
\end{tabular}


Hasil pengukuran kadar asam urat darah tikus menunjukkan efek setelah diberi perlakuan. Pada hasil uji statistik One-way Anova dari data pengukuran kadar asam urat serum darah tikus setelah perlakuan diperoleh hasil perbedaan yng bermakna, atau dengan kata lain terdapat perbedaan rata-rata pada masing-masing kelompok perlakuan. Setelah dilanjutkan dengan Uji statistik LSD didapatkan hasil perbedaan yang bermakna antara masing-masing kelompok.

Rata-rata kadar asam urat pada kelompok perlakuan aquades, allopuriniol, konsentrasi I, konsentrasi II, konsentrasi III, yang dapat dilihat pada gambar 6, menunjukkan perbedaan secara nyata. Pemberian potassium oksonat sebanyak $250 \mathrm{mg} / \mathrm{kgBB}$ pada tikus putih menyebabkan peningkatan kadar asam urat yang nyata pada kelompok kontrol negatif bila dibandingkan dengan kelompok kontrol postif dan ketiga kelompok perlakuan lainnya dengan rata-rata persentase perubahan kadar asam urat setelah perlakuan sebesar $161,282 \%$. Hal ini dikarenakan potassium oksonat menghambat enzim urikase, sehingga pemberian potassium oksonat dapat meningkatkan kadar asam urat dalam darah. Jadi pemberian poattasium oksonat mempunyai efek meningkatkan kadar asam urat dalam darah.

Dalam penelitian initerdapat efek penurunan kadar asam urat yang terjadi pada kelompok kontrol positif dan ketiga kelompok hewan uji yang diberi infusa akar tempuyung yang telah dibuat kadar asam uratnya meningkat dengan pemberian pottasium oksonat. Allopurinol sebagai inhibitor kompetitif dari xantin oksidase sehingga menghambat konversi xantin dan hipoxantin menjadi asam urat, demikian pula infusa akar tempuyung mampu menghambat xantin oksidase sehingga menurunkan kadar asam urat pada tikus putih.

Kelompok kontrol positif mempunyai perbedaan yang bermakna dengan kelompok perlakuan konsentrasi $10 \%$ dan $20 \%$, tetapi tidak mempunyai perbedaan yang bermakna dengan kelompok konsentrasi $40 \%$. Jadi dapat dilihat bahwa efek hipourisemia infusa akar tempuyung konsentrasi $40 \%$ hampir setara dengan allopurinol. Kelompok konsentrasi $40 \%$ rata-rata hasil pengukuran kadar asam uratnya adalah paling besar bila dibandingkan dengan kelompok dosis lainnya. Hal ini menunjukkan konsentrasi $40 \%$ merupakan yang terkuat dalam menurunkan kadar asam urat jika dibandingkan dengan kelompok konsentrasi $10 \%$ dan $20 \%$.

Hal ini menunjukkan infusa akar tempuyung dosis $40 \%$ memiliki efek yang sebanding dengan allopurinol dosis $18 \mathrm{mg} / \mathrm{kgBB}$. Hasil análisis data menunjukkan bahwa dengan adanya perlakuan pemberian infusa akar tempuyung berhasil menurunkan kadar asam urat dalam serum darah pada tikus putih. Dengan demikian hipótesis yang diungkap dalam penelitian mempunyai pengaruh kadar asam urat darah pada tikus putih adalah terbukti kebenarannya.

\section{SIMPULAN}

Infusa akar tempuyung (Sonchus arvensis) pada dosis $1,25 \mathrm{~g} / \mathrm{kgBB}$ (konsentrasi $10 \%$ ), 2,5g/kgBB (konsentrasi 20\%), dan $5 \mathrm{~g} /$ $\mathrm{kgBB}$ (konsentrasi 40\%) mampu menurunkan kadar asam urat serum pada tikus putih (Rattus norvegicus) yang diinduksi dengan potassium oxonat.

\section{Ucapan Terimakasih}

Ucapan terimakasih diajukan kepada dekan dan pengelola Lab. Farmakologi FK UMS

\section{DAFTAR PUSTAKA}

Farid, M. (2007). Pengaruh Ekstrak Daun Tempuyung (Sonchus arvensis) Terhadap Penurunan Kadar Asam Urat Pada Tikus Putih (Rattus norvegicus). Skripsi. Fakultas Kedokteran Universitas Sebelas Maret.

Mahendra, B. (2006). Panduan Meracik Herbal. Jakarta: Penebar Swadaya.

Misnadiarly. (2007). Rematik: Asam UratHiperurisemia, Arthritis Gout. Jakarta: Pustaka Obor Populer.

Pratiknya, A.W. (2001). Dasar-Dasar Metodologi Penelitian Kedokteran dan Kesehatan. Jakarta: Raja Grafindo Persada.Hal: 130133.

Sulaksana, J. (2004). Tempuyung, Budi Daya dan Pemanfaatan Untuk Obat. Jakarta: Penebar

Widisih, W., (2004). Tempuyung: Tanaman Penghancur Batu Ginjal. Jakarta: Agromedia Pustaka. Hal: 1-51.

Yatim, F. (2006). Penyakit Tulang dan Persendian. Jakarta: Pustaka Populer Obor. 